\title{
NITROGEN AND PHOSPHORUS
} FLOW ANALYSIS WITH FOCUS ON ANTHROPOGENIC ORGANIC WASTES: A CASE STUDY IN MANDALAY, MYANMAR

\section{$\operatorname{AUTHOR}(S):$}

NAING, Wutyi; HARADA, Hidenori; FUJII, Shigeo; HMWE, Chaw Su Su

\section{CITATION:}

NAING, WUtyi ...[et al]. NITROGEN AND PHOSPHORUS FLOW ANALYSIS WITH FOCUS ON ANTHROPOGENIC ORGANIC WASTES: A CASE STUDY IN MANDALAY, MYANMAR. 土木学会論文集G(環境) 2018, 74(7): III_367-III_374

\section{ISSUE DATE:}

2018

URL:

http://hdl.handle.net/2433/250798

RIGHT:

(C) 2018 Japan Society of Civil Engineers 


\title{
NITROGEN AND PHOSPHORUS FLOW ANALYSIS WITH FOCUS ON ANTHROPOGENIC ORGANIC WASTES: A CASE STUDY IN MANDALAY, MYANMAR
}

\author{
Wutyi NAING ${ }^{1}$, Hidenori HARADA², Shigeo FUJII², Chaw Su Su HMWE ${ }^{3}$ \\ ${ }^{1}$ D2 Student, Department of Environmental Engineering, Kyoto University \\ (Yoshida-honmachi, Sakyo-ku, Kyoto, Japan) \\ E-mail: wutyi.naing.48z@st.kyoto-u.ac.jp \\ ${ }^{2}$ Member of JSCE, Graduate School of Global Environmental Studies, Kyoto University \\ (Yoshida-honmachi, Sakyo-ku, Kyoto, Japan) \\ E-mail: harada.hidenori.8v@kyoto-u.ac.jp \\ E-mail: fujii.shigeo.6z@kyoto-u.ac.jp \\ ${ }^{3}$ Professor, Department of Chemical Engineering, Mandalay Technological University \\ (Mandalay Technological University, Mandalay, Myanmar) \\ E-mail: chawsusuhmwe@mtu.edu.mm
}

\begin{abstract}
In developing countries, many tons of valuable nutrients (mainly nitrogen $(\mathrm{N})$ and phosphorus $(\mathrm{P})$ ) are lost as waste derived from daily life and agriculture. Nutrient load quantification is an early step for recognizing environmental pollution, and a basic requirement for planning environmental sanitation options. Material flow analysis (MFA) has been used in the environmental sector in many cities of developing countries. In Mandalay, under rapid urbanization, environmental problems have risen to an alarming level. In this study, a nitrogen and phosphorus flow model was developed with a focus on organic waste. The system boundary was five urban townships of Mandalay city and components included in the system were agriculture, livestock, industry, and household. Household surveys, and farmer, livestock owner and industry manager interviews were conducted along with collecting secondary data to develop the model. Results showed that 304 ton-N/year and 258 ton-P/year were discharged from household to the environment as food waste, excreta and greywater. Approximately 3,200 ton- $\mathrm{N}$ from on-site sanitation were also annually released to the environment as toilet effluent/leakage and fecal sludge. Animal manure (83 ton-N/year and 16 ton-P/year) and market waste (456 ton-N/year and 71 ton-P/year) were also observed as losses of valuable resources. Applying nutrients from animal manure, fecal sludge, and organic solid waste in the agricultural sector can reduce the pollution load to the environment, and reduce the chemical fertilizer demand in the city.
\end{abstract}

Keywords: material flow analysis, nitrogen, phosphorus, pollution load, organic waste and wastewater

\section{INTRODUCTION}

With rapid population growth, the world is facing nutrient scarcity. Assuming no change in agricultural practices and the waste-to-food ratio, Liu et al. (2016) estimated that "an additional total nitrogen (TN) of $100 \mathrm{Tg} /$ year will be needed by 2030 for a baseline scenario that would meet hunger alleviation targets for over 9 billion people". At the same time, Phosphorus (P) resources are expected to be depleted in 60-130 years (Schroder et al. 2010). Nitrogen (N) and $\mathrm{P}$ derived from anthropogenic activities as solid wastes and wastewater are leaching into the soil and surface water and many regions have faced serious environmental problems such as eutrophication. For this reason, many countries around the world are initiating strategies to trace the sources and amount of $\mathrm{N}$ and $\mathrm{P}$ from man-made activities to step forward environmental sanitation management and resource recovery options.

Material Flow Analysis (MFA) in particular has been used in many countries to determine pollutant stocks and fluxes related to solid wastes and wastewater, to understand environmental issues. Examples include Denmark (Klinglmair et al. 2017), China (Li et al. 2010; Yuan et al. 2011), Thailand 
(Schaffner et al. 2011; Buathong et al., 2013; Pharino et al. 2016), Vietnam (Giang et al. 2016; Anh et al. 2016; Ta et. al. 2018), and Burkina Faso (Yiougo et al. 2011). In Myanmar, no MFA study has apparently been published to account for the flow, stocks and losses of N and P. Many urban areas in Myanmar are currently facing environmental issues, especially eutrophication. Therefore, visualization and assessment of the quantity of $\mathrm{P}$ and $\mathrm{N}$ flow in the urban developing areas is urgently needed.

Under rapid urbanization, Mandalay is facing many environmental problems and there is no quantitative estimation of the pollution load relating to solid waste and wastewater. This study aims to quantify the $\mathrm{N}$ and $\mathrm{P}$ load of urban Mandalay for a better understanding of the current situation and to contribute to designing alternatives to solve these environmental issues.

\section{MATERIALS AND METHODS}

\section{(1) Study area}

Mandalay city, officially named as Mandalay district including seven townships, is the second largest and densely populated city in Myanmar. The city occupies $912.7 \mathrm{~km}^{2}$ (GAD 2017) with a population of 1.7 million (DOP 2015). This study selected five urban townships (Aung Myae Tharzan, Chan Aye Tharzan, Mahar Aung Maye, Chan Mya Tharzi and Pyi Gyi Dagon) (Fig. 1) which cover 95\% of the city's urban areas $\left(108 \mathrm{~km}^{2}\right)$ and house 1.2 million people (DOP 2015).

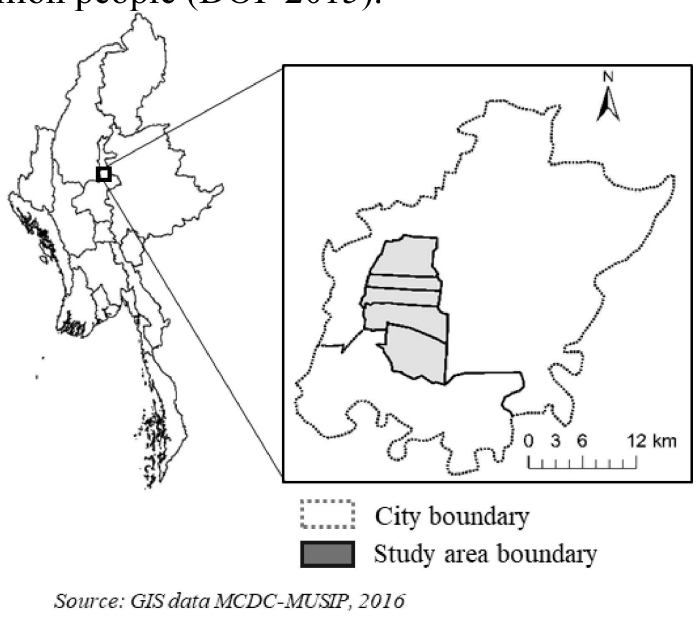

Fig. 1 Map of study area

Currently, the drainage system in the study area is comprised of combined open sewers directly connected to the surface water. There is no centralized treatment facility. Mandalay city development committee (MCDC) is responsible for fecal sludge management. The collection service for fecal sludge is on an "on-call' basis and the estimated collection amount each time is $4.5 \mathrm{~m}^{3}$, while the estimated officially collected and discharged amount to a designated disposal pond is $17,820 \mathrm{~m}^{3} /$ year (MUSIP, 2015). The total number of on-site sanitation facilities (septic tank, cesspool, lined pit and pits etc.) in the targeted area is 213,104 (DOP 2015). Illegal dumping of fecal sludge was observed in the 2014 field survey (Naing et al., 2014). Therefore, the following equation was used to calculate the estimated total amount of fecal sludge removed from on-site sanitation facilities in the targeted area, in which the number of on-site sanitation facilities which were emptied fecal sludge per year was found using the household survey data of the present study.

$$
Q_{\text {total }}=D_{o s} \times N_{o s} \times Q_{f s}
$$

Where, $Q_{\text {total }}$ : Total amount of fecal sludge removed from on-site sanitation facilities $\left(\mathrm{m}^{3} /\right.$ year $)$

$D_{o s}$ : Number of on-site sanitation facilities which were emptied fecal sludge per year

$N_{o s}$ : Number of on-site sanitation facilities in the area $Q_{f s}$ : Estimated amount of fecal sludge collected per trip. $\left(\mathrm{m}^{3}\right)$

\section{(2) Material flow model}

\section{a) Process and system boundary}

With a focus on organic waste and wastewater, $\mathrm{N}$ and $P$ flow models were developed based on Giang et al. (2016). The geographic boundary was limited to the five targeted townships (Fig. 1). Although there might be other $\mathrm{N}$ emission sources, this study focused on organic wastes from specific components and processes (flow of materials from one component to another). The model was composed from ten components $\left(\mathrm{X}_{\mathrm{j}}\right)$ : household $\left(\mathrm{X}_{1}\right)$, on-site sanitation $\left(\mathrm{X}_{2}\right)$, livestock $\left(\mathrm{X}_{3}\right)$, agriculture $\left(\mathrm{X}_{4}\right)$, industry $\left(\mathrm{X}_{5}\right)$ were within the system boundary, while market $\left(\mathrm{X}_{6}\right)$, fecal sludge (FS) disposal pond $\left(\mathrm{X}_{7}\right)$, solid waste (SW) disposal sites $\left(\mathrm{X}_{8}\right)$, ground soil/surface water/ drainage $\left(\mathrm{X}_{9}\right)$, and atmosphere $\left(\mathrm{X}_{10}\right)$ were outside the boundary. The model contains 24 processes (Table. A1 in Appendix). For instance, $\mathrm{P}_{2}$ for human excreta and $\mathrm{P}_{3}$ for greywater discharged from household.

According to the principle of Mass Conservation Law, the net reaction rate of a component within the boundary is equal to zero as following Eq. (2):

$$
r_{j}=\sum_{i}\left(v_{i, j} x \rho_{i}\right)=0
$$

Where, $r_{j}$ : net reaction rate for the component $j$ (ton/year),

$v_{i, j}$ : transfer factor to the component $j$ through reaction process $i(-)$, and

$\rho_{i}$ : reaction rate of reaction process $i$ (ton/year).

Additionally, the mass balance is considered on the 
sum of transfer factors for each reaction process as well as shown in Eq. (3).

$$
f_{j}=\sum_{i}\left(v_{i, j}\right)=0
$$

Where $f_{j}$ : sum of reaction transfer factors for the process $i(-)$.

The reaction process matrix of each reaction process to be calculated is summarized in Table A1 in Appendix A. For example, for the reaction of human excreta discharge $\left(\mathrm{P}_{2}\right)$, the mass flow from the household $\left(\mathrm{X}_{1}\right)$ to on-site sanitation $\left(\mathrm{X}_{2}\right)$ can be designed following Eq. (4) and (5).

$$
\begin{gathered}
f_{X_{1}, X_{2}, P_{1}}=v_{1,2} \times \rho_{1} \\
\rho_{i}=\mathrm{C}_{1, \mathrm{~N}(\mathrm{P})} \times \mathrm{P}_{0} \times 365 \times 10^{-6}
\end{gathered}
$$

Where $f_{X_{1}, X_{2}, P_{1}}$ : mass flow from component $\mathrm{X}_{1}$ to component $X_{2}$ for the process $P_{1}$ (ton/year),

$\mathrm{C}_{1, \mathrm{~N}(\mathrm{P})}: \mathrm{N}(\mathrm{P})$ amount in human excreta (g/cap/day) and

$\mathrm{P}_{0}$ : Population in the study area (person).

\section{(3) Data collection}

\section{a) Primary data collection}

The household survey was conducted on 400 households to limit the expected standard error to less than $5 \%$ at a $95 \%$ confidence interval. The samples were selected from the five urban townships by multi-stage sampling to be proportional to the population. Questionnaires prepared for determining waste and wastewater management at each household included demographic information, water consumption, wastewater management, toilet facilities, fecal sludge management, and kitchen waste management.

In the study area, only one township, Pyi Gyi Dagon, had agricultural land $\left(0.8 \mathrm{~km}^{2}\right)$ (GAD 2017); ten farmers were interviewed on agricultural production, residue management and fertilizer demand. For livestock activities, 21 livestock owners were interviewed on animal production and animal waste management.

There were three industrial zones of the target area in one township, Pyi Gyi Dagon. Of 149 food and beverage factories in these zones (ISD, 2017), factory managers of 65 factories were interviewed on industrial water consumption, wastewater management, solid waste generation and management.

There were 36 markets in the study areas (MCDC 2018). Township Cleansing Departments of five townships, which are responsible for market waste management, were interviewed on waste generation and waste management.

\section{b) Secondary data collection}

The secondary data collected from the literature, including the number, type and size of food and beverage factories in the study area, are summarized in Appendix A (Table A2 and A3). USDA (2018) and JSWA (1999) were referenced for $\mathrm{N}$ and $\mathrm{P}$ concentrations in industrial products, and industrial wastewater respectively.

\section{c) Sensitivity analysis}

In this study, MFA for $\mathrm{N}$ and $\mathrm{P}$ was developed using both primary and secondary data. Data limitations may cause some uncertainty in the calculations. Therefore, the sensitivity analysis was applied to the three major flows to the environment: 1) toilet effluent and 2) greywater from household and 3) wastewater from industry. Sensitivity of 31 parameters was analyzed by following Giang et al. (2016). Since changes in a parameter linearly affect the flows in this model, we analyzed the parameter sensitivity by calculating the impacts, as an example, of a $10 \%$ decrease or increase of each of 31 parameters on the load to the environment.

\section{RESULTS AND DISCUSSION}

\section{(1) Organic solid wastes and wastewater stream}

Interview results of solid wastes and wastewater management are summarized in Table 1. Out of all the households, $98 \%\left(\beta_{2,2}\right)$ were found to have used on-site sanitation, and $2 \%\left(\beta_{2,9}\right)$ directly flushed excreta to surface water or drainage. Out of greywater from households, $1 \%$ was discharged into on-site sanitation facilities, while the remaining $99 \%$ of greywater $\left(\beta_{3,9}\right)$ was directly discharged into drainage, ground soil or surface water. The estimated number of on-site sanitation facilities which were emptied fecal sludge per year $\left(D_{o s}\right)$ was 19,712, then the estimated total amount of fecal sludge removed from on-site sanitation facilities $\left(\mathrm{Q}_{\text {total }}\right)$ was $88,704 \mathrm{~m}^{3} /$ year. Therefore, the official amount of fecal sludge transported to the disposal pond $\left(\beta_{6,7}\right), 17,820 \mathrm{~m}^{3}$ /year (MUSIP, 2015), is equivalent to $20 \%$ of the estimated total amount of fecal sludge removed from on-site sanitation facilities in this study. We assumed the remaining $80 \%\left(\beta_{6,9}\right)$ was improperly discharged directly into the environment.

Almost all of the industrial wastewater was discharged directly into the environment $\left(\mathrm{P}_{20}\right)$. Only nine factories out of 65 had uncontrolled stabilization ponds. Out of the industrial organic solid waste, $11 \%$ was used for livestock feeding activities inside the target area $\left(\beta_{21,3}\right)$, while $72 \%$ was used by livestock feeding activities outside the target area $\left(\beta_{21, \text { out }}\right)$. For 
Table 1 Water consumption and organic load stream for each component calculated from an interview survey.

\begin{tabular}{|c|c|c|c|}
\hline Process & Explanation (symbol) & Unit & Value \\
\hline \multicolumn{4}{|l|}{ Household $\left(\mathrm{X}_{1}\right)$} \\
\hline \multirow[t]{2}{*}{ Human excreta $\left(\mathrm{P}_{2}\right)$} & Ratio of human excreta going to onsite sanitation $\left(\beta_{2,2}\right)$ & - & 0.98 \\
\hline & $\begin{array}{l}\text { Ratio of human excreta going to ground soil/surface } \\
\text { water/drainage }\left(\beta_{2,9}\right)\end{array}$ & - & 0.02 \\
\hline \multirow[t]{2}{*}{ Greywater $\left(\mathrm{P}_{3}\right)$} & Ratio of grey water going to onsite sanitation $\left(\beta_{3,2}\right)$ & - & 0.01 \\
\hline & $\begin{array}{l}\text { Ratio of greywater going to ground soil/surface water/drainage } \\
\left(\beta_{3,9}\right)\end{array}$ & - & 0.99 \\
\hline \multirow[t]{3}{*}{ Kitchen waste $\left(\mathrm{P}_{4}\right)$} & Ratio of kitchen waste going to livestock $\left(\beta_{4,3}\right)$ & - & 0.012 \\
\hline & $\begin{array}{l}\text { Ratio of kitchen waste going to ground soil/surface } \\
\text { water/drainage }\left(\beta_{4,9}\right)\end{array}$ & - & 0.188 \\
\hline & Ratio of kitchen waste going to disposal sites $\left(\beta_{4,8}\right)$ & - & $0.8^{12)}$ \\
\hline \multirow[t]{3}{*}{ Water consumption $\left(\mathrm{P}_{5}\right)$} & Ratio of surface water consumption $\left(\alpha_{\mathrm{sw}}\right)$ & - & 0.05 \\
\hline & Ratio of groundwater consumption by household $\left(\alpha_{\mathrm{gw}}\right)$ & - & 0.95 \\
\hline & Water consumption by household $\left(\mathrm{Q}_{5}\right)$ & $\mathrm{m}^{3} / \mathrm{cap} /$ day & 0.3 \\
\hline \multicolumn{4}{|l|}{ On-site sanitation $\left(\mathrm{X}_{2}\right)$} \\
\hline \multirow[t]{3}{*}{ Fecal sludge $\left(\mathrm{P}_{6}\right)$} & Ratio of fecal sludge going to disposal pond $\left(\beta_{6,7}\right)$ & - & 0.20 \\
\hline & $\begin{array}{l}\text { Ratio of fecal sludge going to ground soil/surface } \\
\text { water/drainage }\left(\beta_{6,9}\right)\end{array}$ & - & 0.80 \\
\hline & $\begin{array}{l}\text { Number of on-site sanitation facilities which were emptied fecal } \\
\text { sludge per year }\left(D_{o s}\right)\end{array}$ & unit/year & 19712 \\
\hline \multirow[t]{2}{*}{ Toilet effluent $\left(\mathrm{P}_{7}\right)$} & Ratio of septic tank (-) & - & 0.84 \\
\hline & Ratio of pit latrine $(-)$ & - & 0.16 \\
\hline \multicolumn{4}{|l|}{ Livestock $\left(X_{3}\right)$} \\
\hline \multirow[t]{2}{*}{ Animal production $\left(\mathrm{P}_{8}\right)$} & Ratio of animal product going to household $\left(\beta_{8,1}\right)$ & - & 0.32 \\
\hline & Ratio of animal product going to market $\left(\beta_{8,6}\right)$ & - & 0.68 \\
\hline \multirow[t]{2}{*}{ Animal manure $\left(\mathrm{P}_{10}\right)$} & $\begin{array}{l}\text { Ratio of manure going to agricultural activities outside the } \\
\text { system boundary }\left(\beta_{10, \text { out }}\right)\end{array}$ & - & 0.57 \\
\hline & $\begin{array}{l}\text { Ratio of manure going to ground soil/surface water/drainage } \\
\left(\beta_{10,9}\right)\end{array}$ & - & 0.43 \\
\hline Water consumption $\left(\mathrm{P}_{11}\right)$ & Amount of water consumption $\left(\mathrm{Q}_{11}\right)$ & $\mathrm{m}^{3} /$ day & 822 \\
\hline \multicolumn{4}{|l|}{ Agriculture $\left(\mathrm{X}_{4}\right)$} \\
\hline \multirow{2}{*}{$\begin{array}{l}\text { Agricultural production } \\
\left(\mathrm{P}_{13}\right)\end{array}$} & Amount of agricultural production $\left(\mathrm{P}_{\text {agri(rice) }}\right)$ & ton/year & 510 \\
\hline & Amount of agricultural production $\left(\mathrm{P}_{\text {agri(veg }}\right)$ & ton/year & 1185 \\
\hline \multirow[t]{5}{*}{ Agricultural residue $\left(\mathrm{P}_{14}\right)$} & $\begin{array}{l}\text { Ratio of agricultural residue going to livestock feeding (rice) } \\
\left(\beta_{14,3 \text { (rice) })}\right.\end{array}$ & - & 0 \\
\hline & $\begin{array}{l}\text { Ratio of agricultural residue going to livestock feeding (veg) } \\
\left(\beta_{14,3(\mathrm{veg})}\right)\end{array}$ & - & 0.16 \\
\hline & Ratio of agricultural residue going to agriculture (rice) $\left(\beta_{14,4 \text { (rice) }}\right)$ & - & 1 \\
\hline & Ratio of agricultural residue going to agriculture (veg) $\left(\beta_{14,4(\mathrm{veg})}\right)$ & - & 0.64 \\
\hline & Ratio of agricultural residue going to burning (veg) $\left(\beta_{14, \text { burn }}\right)$ & - & 0.20 \\
\hline \multirow[t]{3}{*}{ Fertilizer $\left(\mathrm{P}_{16}\right)$} & Amount of chemical fertilizer demand $\left(\mathrm{Q}_{16}\right)$ & $\mathrm{kg} / \mathrm{m}^{2}$ & 0.013 \\
\hline & $\mathrm{N}$ proportion in chemical fertilizer $\left(\mathrm{C}_{16 \mathrm{~N}}\right)$ & $\%$ & $15-27$ \\
\hline & $P$ proportion in chemical fertilizer $\left(\mathrm{C}_{16 \mathrm{P}}\right)$ & $\%$ & $0-19$ \\
\hline \multicolumn{4}{|l|}{ Industry $\left(\mathrm{X}_{5}\right)$} \\
\hline Industrial production $\left(\mathrm{P}_{19}\right)$ & Amount of industrial production $\left(\mathrm{Q}_{19}\right)$ & ton/year & 313282 \\
\hline Industrial wastewater $\left(\mathrm{P}_{20}\right)$ & Amount of wastewater generated $\left(\mathrm{Q}_{20}\right)$ & $\mathrm{m}^{3} /$ year & 8839117 \\
\hline \multirow[t]{6}{*}{ Industrial solid waste $\left(\mathrm{P}_{21}\right)$} & $\begin{array}{l}\text { Ratio of industrial solid waste used for livestock feeding } \\
\text { activities inside the system boundary }\left(\beta_{21,3}\right)\end{array}$ & - & 0.11 \\
\hline & $\begin{array}{l}\text { Ratio of industrial solid waste used for livestock feeding } \\
\text { activities outside the system boundary }\left(\beta_{21, \text { out }}\right)\end{array}$ & - & 0.72 \\
\hline & Ratio of industrial solid waste going to disposal sites $\left(\beta_{21,8}\right)$ & - & 0.11 \\
\hline & Ratio of industrial solid waste going to soil/surface water $\left(\beta_{21,9}\right)$ & - & 0.03 \\
\hline & Ratio of industrial solid waste to burning $\left(\beta_{21, \text { burn }}\right)$ & - & 0.03 \\
\hline & Amount of industrial organic solid waste generation $\left(\mathrm{Q}_{21}\right)$ & ton/year & 73403 \\
\hline Water consumption $\left(\mathrm{P}_{22}\right)$ & Amount of water consumption $\left(\mathrm{Q}_{22}\right)$ & $\mathrm{m}^{3} /$ year & 9184644 \\
\hline \multicolumn{4}{|l|}{ Market $\left(X_{6}\right)$} \\
\hline \multirow[t]{3}{*}{ Market leftover $\left(\mathrm{P}_{24}\right)$} & Ratio of market waste going to animal feeding $\left(\beta_{24,3}\right)$ & - & 0.05 \\
\hline & Ratio of market waste going to disposal sites $\left(\beta_{24,8}\right)$ & - & 0.95 \\
\hline & Amount of market waste generated (organic) $\left(\mathrm{Q}_{24}\right)$ & ton/day & 51 \\
\hline
\end{tabular}

Note: 12) MCDC, 2016 
the remaining $17 \%$ not used by feeding, $11 \%$ was transported to disposal sites, $3 \%$ was left or discarded nearby (ground soil/drainage/surface water) $\left(\beta_{21,9}\right)$, and $3 \%$ was burnt $\left(\beta_{21, \text { burn }}\right)$.

Livestock farming used $1.2 \%$ of kitchen waste from households $\left(\beta_{4,3}\right), 16 \%$ of vegetable residue $\left(\beta_{14,3(\mathrm{veg})}\right), 11 \%$ of industrial organic waste $\left(\beta_{21,3}\right)$, and $5 \%$ of market organic waste $\left(\beta_{24,3}\right)$ as feed. However, $43 \%$ of animal manure $\left(\beta_{10,9}\right)$ was also discharged directly into the drainage, while $57 \%$ $\left(\beta_{10, \text { out }}\right)$ was used for agricultural activities implemented outside of the study area. No farmer using organic waste and/or animal manure was observed in this study. Chemical fertilizer demand was $0.013 \mathrm{~kg} / \mathrm{m}^{2}\left(\mathrm{Q}_{16}\right)$. A large proportion of the agricultural residue was left in farmlands $\left(\beta_{14,4}\right)$ : $100 \%$ by rice farmers and $64 \%$ by vegetable farmers. As mentioned before, only $16 \%$ of the vegetable residue $\left(\beta_{14,3(\mathrm{veg})}\right)$ was used for animal feed; the other $20 \%$ were burnt on the fields $\left(\beta_{14, \text { burn }}\right)$.

Together with other municipal solid waste, $95 \%$ of the market organic solid waste $\left(\beta_{24,8}\right)$ and $80 \%$ of household food $\left(\beta_{4,8}\right)$ was transported to disposal sites. For the remaining $20 \%$ of food waste, $19 \%$ was discarded into the environment $\left(\beta_{4,9}\right)$.

\section{(2) $\mathrm{N}$ and $\mathrm{P}$ flow among components}

Material flow models of $\mathrm{N}$ and $\mathrm{P}$ are shown in Fig. 2 and 3. By summing up the amount of nutrient outputs from each component (household $\left(\mathrm{X}_{1}\right)$, onsite sanitation $\left(\mathrm{X}_{2}\right)$, livestock $\left(\mathrm{X}_{3}\right)$, agriculture $\left(\mathrm{X}_{4}\right)$ and industry $\left(\mathrm{X}_{5}\right)$ ) to the environment (ground soil/surface water/drainage) $\left(\mathrm{X}_{9}\right)$, the total nutrient outputs from the system to the environment were 4037 ton-N/year and 779 ton-P/year. The five largest flows to the environment in descending order for $\mathrm{N}$ were toilet effluent/leakage, industrial wastewater, greywater from household, animal manure from livestock, and human excreta from household. For P, these were toilet effluent/leakage, greywater from household, food waste from household, industrial wastewater, and animal manure from livestock. The details of $\mathrm{N}$ and $\mathrm{P}$ flows are discussed in the following sections.

\section{a) Household and on-site sanitation}

Households generated the largest flow among the five components inside the boundary, discharging 304 ton-N and 258 ton-P into the environmental annually. 72 ton-N (24\%) and 11 ton-P (4\%) of this was human excreta, 177 ton-N (58\%) and 177 ton-P $(69 \%)$ was greywater and 55 ton-N $(18 \%)$ and 70 ton$\mathrm{P}(27 \%)$ was food waste.

From the household, greywater represented the largest flow to the environment for both $\mathrm{N}$ and $\mathrm{P}$. Therefore, reducing the pollution load from household is a critical concern in this area. Moreover, household generated 291 ton-N/year and 371 ton$\mathrm{P} /$ year as food waste totally, from which 233 ton-N and 297 ton-P were collected and disposed of at disposal site $(80 \%), 55$ ton- $\mathrm{N}$ and 70 ton-P discharged to the environment (19\%), and livestock sector used 3 ton-N and 4 ton-P per year (1.2\%). Similar to household food waste, $95 \%$ (456 ton$\mathrm{N} /$ year and 71 ton-P/year) of market organic solid waste was disposed of at the solid waste disposal site and the remaining 5\% (24 ton-N/year and 4 ton$\mathrm{P} /$ year) was used for livestock feeing activities. Therefore, a total of 744 ton-N/year and 437 ton$\mathrm{P} /$ year of nutrients as food waste and market organic wastes were estimated as a loss of resources. If these organic wastes were separately collected, they could be used as fertilizer for the agricultural sector by composting and as animal feeding for the livestock sector. Therefore, organic solid waste from the household and market sectors had high potential for resource recovery if waste separation and recycling could be enhanced in the study area.

On-site sanitation received the largest $\mathrm{N}$ and $\mathrm{P}$ flows in the system, which were 3,551 ton- $\mathrm{N}$ and 526 ton- $\mathrm{P}$ as human excreta and 2 ton- $\mathrm{N}$ and 2 ton- $\mathrm{P}$ as greywater from household. Effluent and leakage from on-site sanitation were the largest $\mathrm{N}$ and $\mathrm{P}$ flows in the system, which were 3,140 ton-N/year and 411 ton-P/year. Proper management of effluent and leakage from on-site sanitation is crucial to decrease the pollution load to the environment. Moreover, 38 ton-N/year and 11 ton-P/year of fecal sludge was directly dumped into the environment. As mentioned above, only $20 \%$ of fecal sludge is estimated to be disposed of at a designated disposal pond. This study recommends the promotion of sound collection, transportation to the designated site, and appropriate treatment of fecal sludge, ideally with resource recovery.

\section{b) Industry, livestock, agriculture}

The industrial zones discharged 451 ton-N and 81 ton-P annually, in which 394 ton-N (87\%) and 63 ton-P $(78 \%)$ was due to wastewater and 57 ton-N $(13 \%)$ and 18 ton-P (22\%) was due to solid waste. This means the industrial sector stood as the second largest nitrogen pollution output from the system to the environment. For that reason, the proper management of solid waste and wastewater from the industrial zones is a priority. In particular, industrial organic wastes had great potential to be used as resources as they were being used for livestock feeding intensively; 1368 ton-N (72\%) and 212 ton$\mathrm{P}(72 \%)$ were used as outside of the area and 204 ton$\mathrm{N}(11 \%)$ and 32 ton-P (11\%) inside of the area.

Livestock played a key role in resource recovery, which received $\mathrm{N}$ and $\mathrm{P}$ as organic solid waste from different sectors: in total 231.5 ton-N/year and 40.1 


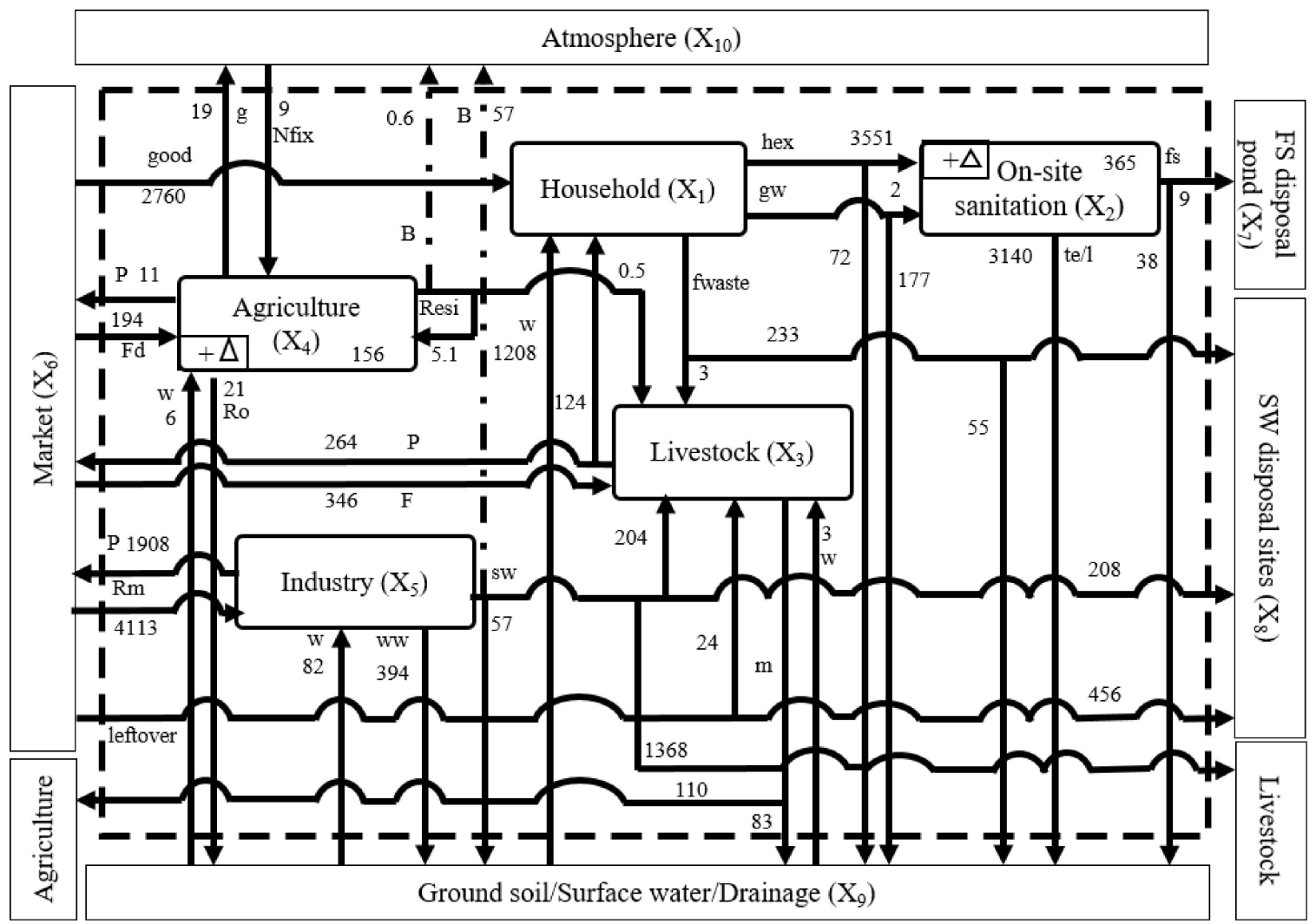

Fig. 2 Material flow model of $\mathrm{N}$ (ton-N/year). hex $=$ human excreta, $g w=$ greywater, fwaste $=$ food waste, $w=$ water, $f s=f e c a l$ sludge, te $/ \mathrm{l}=$ toilet effluent/leakage, $\mathrm{P}=$ production, $\mathrm{F}=$ feeding, $\mathrm{m}=$ manure, $\mathrm{Nfix}=\mathrm{N}$ fixation, $\mathrm{Resi}=$ residue, $\mathrm{Fd}=\mathrm{chemical}$ fertilizer demand, $\mathrm{g}=$ gas, $\mathrm{Ro}=$ runoff, $\mathrm{ww}=$ wastewater, $\mathrm{sw}=$ solid waste, $\mathrm{B}=$ burn, $\mathrm{Rm}=$ raw material

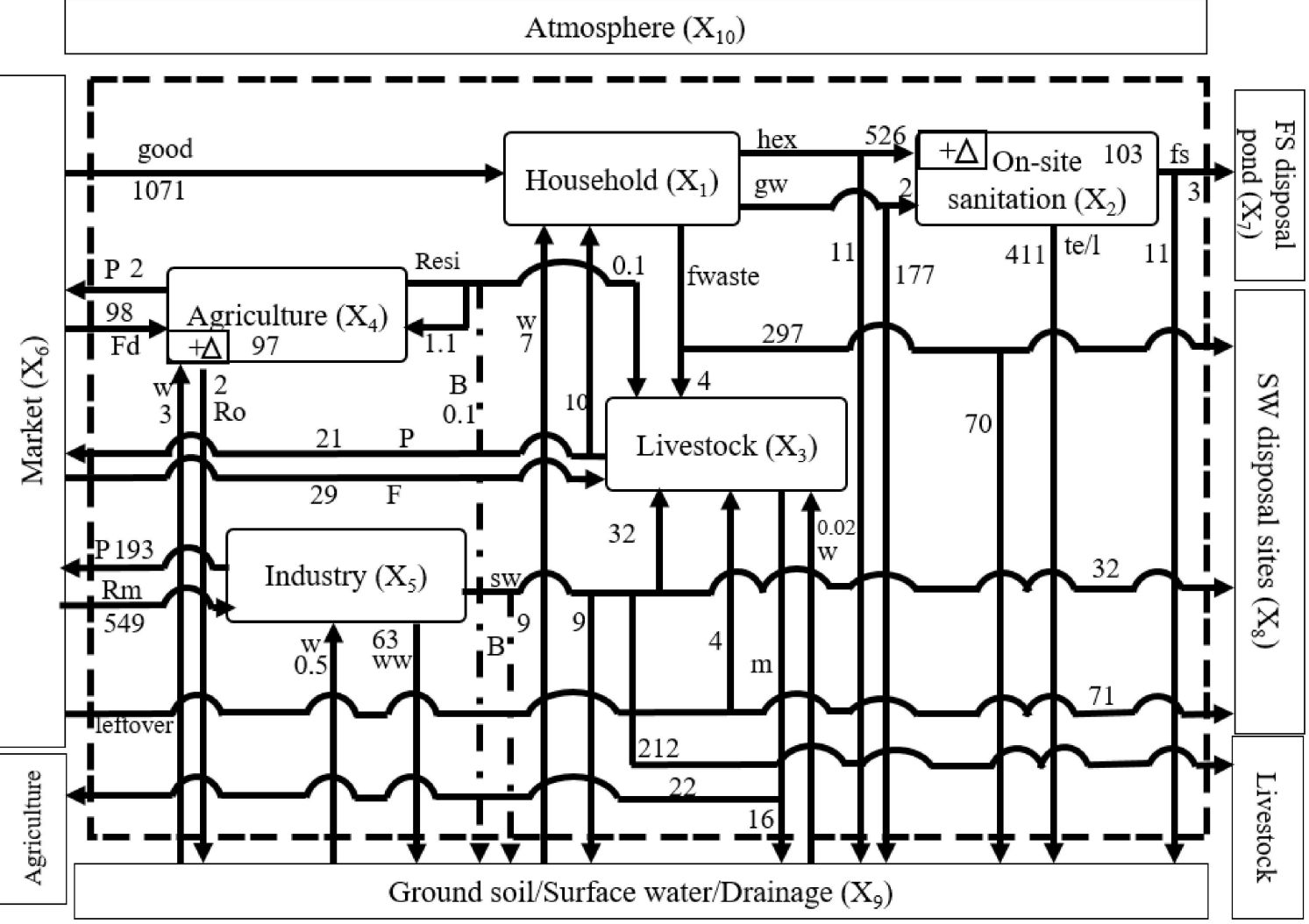

Fig. 3 Material flow model of $\mathrm{P}$ (ton-P/year). hex $=$ human excreta, $\mathrm{gw}=$ greywater, fwaste $=$ food waste, $w=$ water, $f \mathrm{~s}=\mathrm{fecal}$ sludge, te $/ \mathrm{l}=$ toilet effluent/leakage, $\mathrm{P}=$ production, $\mathrm{F}=$ feeding, $\mathrm{m}=$ manure, $\mathrm{Nfix}=\mathrm{N}$ fixation, $\mathrm{Resi}=$ residue, $\mathrm{Fd}=\mathrm{chemical}$ fertilizer demand, $\mathrm{g}=$ gas, $\mathrm{Ro}=$ runoff, $\mathrm{ww}=$ wastewater, $\mathrm{sw}=$ solid waste, $\mathrm{B}=\mathrm{Burn}, \mathrm{Rm}=$ raw material. 
ton-P/year, composed of industrial organic solid waste (204 ton-N and 32 ton-P), market organic solid waste (24 ton-N and 4 ton-P), and other organic solid waste ( 3.5 ton-N and 4.1 ton-P). The organic solid waste utilized at livestock was equivalent to $8 \% \mathrm{~N}$ and $5 \% \mathrm{P}$ of total organic solid waste generation of the area. Although livestock utilized a large amount of nutrients from the system, it was still a significant contributor of $\mathrm{N}$ and $\mathrm{P}$ loads to the environment. Although $57 \%$ of animal manure was used for agriculture outside of the city, $43 \%$ of livestock manure was discarded to the environment, which was equivalent to 83 ton-N/year and 16 ton-P/year. Agricultural activities did not play an important role for nutrient recycling from organic waste, since the agricultural activity itself is not active in the urban area. Consequently, recycling animal manure should be promoted outside the urban area, especially for the reduction of nitrogen load.

\section{c) Estimated impacts by the types of waste}

To enhance the resource recovery opportunity, food waste from household (288 ton-N/year and 367 ton-P/year), market organic waste (456 ton-N/year and 71 ton-P/year), and Industrial organic solid waste (322 ton-N/year and 50 ton-P/year) can be major sources of resource recovery. Food waste from household, organic solid waste from industry, manure from livestock and fecal sludge from on-site sanitation represented $6 \%$ of $\mathrm{N}$ and $15 \%$ of $\mathrm{P}$ pollution load to environment.

Apart from solid waste, industrial wastewater contributed to $10 \% \mathrm{~N}$ and $8 \% \mathrm{P}$ of the pollution load. If it is treated properly or used as resources (for example in gardening, or recycled for factory floor cleansing or boiler water), it can reduce the impact to the environment. Greywater from household contributed $4 \%$ of $\mathrm{N}$ and $23 \%$ of $\mathrm{P}$ loads to the environment. With proper greywater management, the impacts of the pollution load to the environment can be reduced. Although solid waste utilization as resources enhances the material cycle, proper wastewater management is more important to reduce pollution loads to the freshwater and marine environments.

Finally, toilet effluent/leakage for on-site sanitation contributed $78 \%$ of $\mathrm{N}$ and $53 \%$ of P pollution load to the environment. Therefore, proper management of on-site sanitation would have the greatest impact on the pollution load in this study area.

\section{SENSITIVITY ANALYSIS}

The sensitivity analysis was applied on parameters used for three major flows to the environment (ground soil/surface water/drainage): toilet effluent from on-site sanitation, greywater from household, and wastewater from industry. As shown in Table 2, population, nutrient concentration in greywater, nutrient concentration in human excreta and industrial wastewater generation and effluent concentration in jelly/candy industries had the highest sensitivity on both $\mathrm{N}$ and $\mathrm{P}$. These results indicate that the treatment of greywater from household and the treatment of industrial wastewater had a bigger impact than other parameters on the estimation of the pollution load to the environment in this area.

Table 2. Effect of $10 \%$ increase in the most five sensitive parameters of three major flows on total load to the environment.

\begin{tabular}{|c|c|c|}
\hline \multirow[t]{2}{*}{ Parameter } & \multicolumn{2}{|c|}{$\begin{array}{l}\text { Ratio of the after- } \\
\text { increase to the before- } \\
\text { increase (-) }\end{array}$} \\
\hline & $\mathrm{N}$ & $\mathrm{P}$ \\
\hline Population & 1.01 & 1.03 \\
\hline Nutrient concentration in greywater & 1.01 & 1.03 \\
\hline Nutrient concentration in human excreta & 1.08 & 1.05 \\
\hline $\begin{array}{l}\text { Industrial wastewater effluent } \\
\text { concentration in jelly/candy industries }\end{array}$ & 1.08 & 1.08 \\
\hline $\begin{array}{l}\text { Industrial wastewater generation from } \\
\text { jelly/candy industries }\end{array}$ & 1.08 & 1.08 \\
\hline
\end{tabular}

\section{CONCLUSIONS}

As a case study in Mandalay city, Myanmar, this study developed $\mathrm{N}$ and $\mathrm{P}$ flows with a focus on organic solid waste and wastewater, including both domestic and industrial sectors. It was estimated that the total pollution load to the environment was 4,037 ton-N and 779 ton-P every year. Toilet effluent/leakage from on-site sanitation was the heaviest flow of both $\mathrm{N}$ and P. Industrial wastewater, household greywater and animal manure were major flows of $\mathrm{N}$ to the environment, while greywater, household food waste and industrial wastewater were major flows of P. From the aspect of resource recovery, livestock sectors played a major role on the present condition, receiving $8 \%$ of $\mathrm{N}$ and $5 \%$ of $\mathrm{P}$ from household, industry, market and agricultural sectors as organic wastes. Agricultural activities were not active in recycling organic waste in this study area. Organic solid waste, fecal sludge and manure represented $6 \%$ and $15 \%$; industrial wastewater represented $10 \%$ and $8 \%$; greywater represented $4 \%$ and $23 \%$; and toilet effluent/leakage represented $78 \%$ and $53 \%$ of $\mathrm{N}$ and $\mathrm{P}$ pollution load to the environment, respectively. Moreover, industrial wastewater generation and effluent concentration from 
jelly/candy industries had the highest sensitivity on both $\mathrm{N}$ and $\mathrm{P}$ load to the environment. This is useful knowledge for further improvement of waste, wastewater and fecal sludge management planning.

However, there are some limitations of this study. Due to the lack of secondary data, the study used N and $\mathrm{P}$ concentrations from the existing available literature from similar geographic and demographic condition areas. Moreover, $\mathrm{N}$ and $\mathrm{P}$ concentrations for industrial wastewater and food composition were calculated by using Japanese and US guideline values, respectively. As indicated by the sensitivity analysis, greywater concentration and excreta concentration were the most influential parameters. For more accurate analysis, these parameters need to be investigated. In spite of the aforementioned limitations, the material flow model developed in this study successfully quantified the flow of $\mathrm{N}$ and $\mathrm{P}$ in the target city with a focus on anthropogenic organic waste flows to the environment, which is important foundational information for waste and wastewater management in the area.

ACKNOWLEDGMENT: This study was funded by grants of Japan Society for the Promotion of Science KAKENHI (No. JP16H02748). Survey group from MTU, MCDC, GAD, ISD and Environmental Conservation Department were also supported for conducting surveys in Mandalay, Myanmar.

\section{APPENDIX}

The following additional information is available online (http://mydo.cx/YmJkY2Jm).

Table A1. Reaction process matrix of MFA

Table A2. Collected secondary data used in MFA

Table A3. Number, type and size of food and beverage factories in Mandalay

\section{REFERENCES}

1) Anh, T. N. Q., Harada, H., Fujii, S., Anh, P. N., Lieu, P. K., \& Tanaka, S. (2016). Preliminary analysis of phosphorus flow in Hue Citadel. Water Science and Technology, 73(1), 69-77. https://doi.org/10.2166/wst.2015.463

2) Buathong, T., Boontanon, S. K., Boontanon, N., Surinkul, N., Harada, H., \& Fujii, S. (2013). Nitrogen Flow Analysis in Bangkok City, Thailand: Area Zoning and Questionnaire Investigation Approach. Procedia Environmental Sciences, 17, 586-595. https://doi.org/10.1016/j.proenv.2013.02.074

3) DOP (Department of Population) (2015). The republic of the Union of Myanmar. The 2014 Myanmar Population and Housing Census report. vol 3-1 (May).

4) GAD (General Administration Department) (2017). Regional data report, Mandalay district, 2017. (in Burmese)

5) GAD (General Administration Department) (2017). Regional data report, Mandalay district, Pyigyitagon township, 2017. (October) (in Burmese)

6) Giang, P. G., Harada, H., Fujii, S., Nguyen, P. H. L., \& Huynh, T. H. (2016). Transition of human and livestock waste management in rural Hanoi: a material flow analysis of nitrogen and phosphorus during 1980-2010. Journal of Material Cycles and Waste Management, (1), 1-13.

7) ISD (Industrial Supervision Department) (2017). List of private industrial enterprises in the Mandalay industrial zones. (October) (in Burmese)

8) JSWA (Japan Sewage Works Association) (1999). Survey on Sewage Development Comprehensive Plan for watershed areas: Guidelines and Explanation. (Ryuiki betsu gesuidou seibi sougou keikaku chousa: Shishin to kaisetsu) (in Japanese)

9) Klinglmair, M., Vadenbo, C., Astrup, T. F., \& Scheutz, C. (2017). An MFA-based optimization model for increased resource efficiency: Phosphorus flows in Denmark. Resources, Conservation and Recycling, 122, 1-10.

10) Li, S., Yuan, Z., Bi, J. \& Wu, H. (2010). Anthropogenic phosphorus flow analysis of Hefei City, China. Science of the Total Environment 408, 5715-5722.

11) Liu, J., Ma, K., Ciais, P., \& Polasky, S. (2016). Reducing human nitrogen use for food production. Scientific Reports, 6, 1-14. https://doi.org/10.1038/srep30104

12) MCDC (Mandalay City Development Committee) (2016). Mandalay 2020 - Clean and Green: The City of Nature Urban Services Business Operation Plan for Solid Waste Management. September: 1-57.

13) MCDC. (2018). List of Market names in each township under Market and Slaughter Department, MCDC. received on 5th March,2018. (in Burmese)

14) MUSIP (Mandalay Urban Services Improvement Project) (2015). TA-8472 MYA: Preparing Mandalay Urban Services Improvement Project Final Report, Volume 5.

15) Naing, W. (2016). Master Thesis on Key Determinants of Fecal Sludge Management Planning in Myanmar and Thailand: Case Studies in Mandalay City and Nonthaburi Municipality. (May).

16) Pharino, C., Sailamai, N., and Kamphaengthong, P.L. (2016). Material Flow Analysis of Nitrogen in Maeklong River Basin in Ratchaburi and Samut Songkhram Province, Thailand. Water Conservation Science and Engineering 1 (3)., 167-75. https://doi.org/10.1007/s41101-016-0011-1.

17) Schaffner, M., Bader, H. P., \& Scheidegger, R. (2011). Modeling non-point source pollution from rice farming in the Thachin River Basin. Environment, Development and Sustainability, 13(2), 403-422.

18) Schroder, J. J., Cordell, D., Smit, A. L. \& Rosemarin, A. (2010). Sustainable Use of Phosphorus. Plant Research International, Wageningen UR, The Netherlands.

19) Ta, T. T., Trinh, D. A., \& Do, N. T. (2018). Nitrogen flow assessment in rapidly urbanizing Hai Duong province, downstream of Cau River Basin, Vietnam. Journal of Material Cycles and Waste Management, 20(1), 533-542.

20) USDA (United States Department of Agriculture). (2018). National Nutrient Database for Standard Reference 1 Release April, 2018. Software developed by the National Agricultural Library v.3.9.4 2018-05-02. retrieved at https://ndb.nal.usda.gov/ndb/foods/show/301876?manu=\& fgcd $=\& d s=S R$

21) Yiougo, L. S. A., Koanda, H., Wethe, J., Luthi, C., Yapo, O., \& Dapola, E. D. (2011). The method of material flow analysis, a tool for selecting sustainable sanitation technology options: The case of Pouytenga (Burkina Faso). WIT Transactions on Ecology and the Environment, 145.

22) Yuan, Z., Shi, J., Wu, H., Zhang, L.\&Bi, J. (2011). Understanding the anthropogenic phosphorus pathway with substance flow analysis at the city level. Journal of Environmental Management 92, 2021-2018.

(Received May 17, 2018) 